\title{
Arctic Drilling Workshop, OtTAWA, June 23-24, 1988
}

\section{By Randall Jacobson}

To environments because of their cold hydrospheres and because of ice caps on adjacent land masses. These environments are the result of a long-term climate change since the end of the Mesozoic and shortterm recurring climate shifts between late Cenozoic glacials and interglacials. Studies of the marine depositional environments and sediments that record this evolution have provided important but fragmentary data to describe the onset of the cold polar climate since late Neogene time and the response of fauna and flora to the cold temperatures. Virtually nothing is known of the transition period.

The evolution of the cold hydrospheres has also had a major impact on the hydrography of the world's oceans, because as the surface waters of the polar oceans cool. they sink and flow equatorward to fill the deep-sea basins. Climatic evolution in the polar regions theretore has global impact on the world's ocean and atmosphere, as well as on the biosphere. To trace this evolution from its probable onset in the late Mesozoic to the present is a first-order geoscientific problem that can be solved only by studying the history of the polar oceans. The sediment record of the southern oceans is quite well known from long piston cores and drill samples from the Deep-Sea Drilling Project. The Arctic, however, is much less well known.

Knowledge of the Arctic Ocean has more than regional importance. because the Arctic is linked to the evolution of the adjacent oceanic basins and continents. An understanding of past and present plate movements in the Arctic will be required before a complete model of late Mesozoic and Cenozoic northern hemisphere plate motions can be achieved. These motions and the structure, paleontology and paleoenvironment of the sedimentary rock sequences of the circumpolar regions and its continental shelves are highly relevant to the exploration for hydrocarbons. Recognizing the critical need for scientific

Randall Jacobion. Office of Naval Rese'urch, Corde

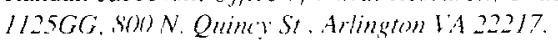

deep-ocean sampling in the Arctic. an international effort has begun, aimed at organizing a major drilling expedition that will also serve as the focus of other polar experiments.

In December 1986, the Geological Survey of Canada (GSC) and subgroups of the International Union of Geology and Geophysics and the International Union of Geodesy and Seismology sponsored a workshop that was attended by Arctic drilling experts and aimed at assessing the technical feasibility of Arctic deep drilling. The workshop concluded that such drilling would be complicated and costly but feasible with existing industry and Ocean Drilling Project technology. A key element of an Arctic drilling effort is a Class 8 ice-rated research platform, which the Government of Canada has committed itself to construct. A two day meeting held at the GSC in Ottawa on June 23 and 24. 1988, addressed the status of the international effort. pinpointed specific objectives and targets, evaluated the capabilities of the proposed Class 8 platform, and organized future efforts.

A number of methods were discussed for recovering Arctic seafloor samples. These included large corers operated from the new Swedish and Canadian icebreakers. "gattling gun" bottom mounted corers. remotely-operated vehicles for sampling escarpments, a light drilling rig mounted on the Canadian Class 8 platform, and a frozen-in commercial drilling rig. It was the clear consensus that a multifaceted approach to take advantage of any opportunity was needed.

In August 1988, an Executive Committee chaired by Norway was established; Canada will provide the secretariat. The relationship of this organization to the International Council of Scientific Unions and to other Arctic committees will be investigated.

The meeting was attended by representatives from Canada, the Federal Republic of Germany, Norway, the Soviet Union, Sweden, and the United States.

VEETINGS AVD WORKSHOPS

\section{U.K. OCEANOGRAPHY 88}

\section{By David Pugh}

To misquote a famous Mississippi hydrologist. new's of the death of British oceanography has been greatly exaggerated. This was certainly the opinion of more than 200 oceanographers who attended a one week meeting entitled "U.K. Oceanography 88." held during 12-16 September 1988 at the University of East Anglia under the auspices of The Challenger Society.

More than 70 papers were presented on topics of chemical and physical oceanography and sediment dynamics. Jim Galloway, of the University of Virginia, while presenting an invited talk on atmospheric inputs in the Atlantic Ocean from North America, commented on the high standard of papers and their presentation by young scientists. A special prize was instituted in memory of Norman Heaps, who was for many years a leading numerical modeler at the Proudman Oceanographic Laboratory.

David Pugh. Instutate of Oceanographto Sciences. Dearon Laboratory, Wormlex. Godalming. U.K.
The prize was shared between Adrian New, Institute of Oceanographic Sciences, Deacon Laboratory, for his paper on "Internal Tides and Mixing in the Bay of Biscay," and Andrew Rees and Simon Wakefield. Plymouth Polytechnic and Swansea, for their paper on "The Behaviour of Dissolved Iron and Manganese in a Highly Disturbed Sediment in Swansea Bay."

The meeting was the third in a biennial series consisting of a mixture of keynote lectures and shorter presentations. Dr. Jim Andrews (ONR, London) gave an evening lecture on "Naval Oceanography: Tautology or Oxymoron," a title sufficiently obscure to attract a large audience and generate a vigorous discussion. At the conference dinner the chairman of the organizing committee, Peter Liss, announced that the next "U.K. Oceanography" will be held in Plymouth. Devon, in September 1990: the next organizing committee will be chaired by Keith Dyer. 